\title{
KOMPETENSI MENGAJAR CALON GURU SD \\ (Studi Kasus Mahasiswa Program Studi PGSD FKIP Universitas Muhammadiyah Palangkaraya)
}

\author{
ADY FERDIAN NOOR \& FAZAKKIR NOOR \\ Dosen pada Fakultas Keguruan dan Ilmu Pendidikan \\ Universitas Muhammadiyah Palangkaraya
}

\begin{abstract}
Teacher competence is at stake when it is performing its duties to teach subjects. Teaching requires a confident, able to appear, the sound loud and clear and kharakter / characteristic. Teach a person's ability to be able to control the situation and conditions in the classroom so that the learning process takes place as planned. Students studies program PGSD FKIP Muhammadiyah University of Palangkaraya as prospective elementary school teachers improve teaching competence is necessary. Based on that idea, researchers interested in examining Competence Teaching Elementary Teacher Candidates (Case Study Students studies program PGSD FKIP Muhammadiyah University of Palangkaraya).

The method used qualitative research methods case study type. This qualitative study using this type of case research strategy. Riduwan (2005) suggested Qualitative Methods is a research method that is used examine the condition of scientific objects, where the researcher is a key instrument. Qualitative research uses the natural environment as a data source directly. Situation good education within the family, school and community, as it is (naturally) without any changes and intervention by the researcher, is the object of qualitative research. Silalahi (2003:62) and Sudjana and Ibrahim (2001:69-71) argues the case study are (a) a study that will involve us in a more in-depth investigation and a thorough examination of the behavior of an individual, (b) research on the background rear and conditions of individuals, groups, or communities with the aim to provide a complete picture of the subject or event under study, and (c) a study conducted intensive, detailed and in-depth on the organism, institution or certain symptoms. This case study is used as the subject under study narrow and limited.

The results of the research that students Studies Program PGSD FKIP Muhammadiyah University of Palangkaraya year class of 2012 perform individual tasks and task groups is seen that the ability to teach students, especially in terms of confidence, dare to appear, the sound loud and clear and the characters / characteristic that has not been fully owned also less able to control the situation and condition of class.
\end{abstract}

Keywords: teaching competence, prospective elementary teachers

\section{ABSTRAK}

Kompetensi seorang guru sangat dipertaruhkan apabila sedang melaksanakan tugasnya mengajar mata pelajaran. Mengajar memerlukan percaya diri, berani tampil, suara keras dan jelas dan kharakter/ciri khas. Mengajar merupakan kemampuan seseorang untuk dapat menguasai situasi dan kondisi di dalam kelas sehingga proses pembelajaran berlangsung sesuai rencana. Mahasiswa Program Studi PGSD FKIP Universitas Muhammadiyah Palangkaraya sebagai calon guru sekolah dasar sangat perlu memperbaiki kompetensi mengajar. Berdasarkan pemikiran tersebut peneliti tertarik meneliti Kompetensi Mengajar Calon Guru SD (Studi Kasus Mahasiswa Program Studi PGSD FKIP Universitas Muhammadiyah Palangkaraya).

Metode penelitian yang digunakan metode penelitian kualitatif jenis studi kasus. Penelitian kualitatif ini menggunakan jenis strategi penelitian kasus. Riduwan (2005) mengemukakan Metode Kualitatif adalah metode penelitian yang digunakan meneliti pada kondisi objek ilmiah, dimana peneliti adalah sebagai instrument kunci. Penelitian kualitatif menggunakan lingkungan alamiah sebagai sumber data langsung. Situasi pendidikan baik dalam lingkungan keluarga, sekolah dan masyarakat, sebagaimana adanya (alami) tanpa dilakukan perubahan dan intervensi oleh peneliti, merupakan objek bagi penelitian kualitatif. Silalahi (2003:62) dan Sudjana dan Ibrahim (2001:69-71) mengemukakan penelitian kasus adalah (a) studi yang akan melibatkan kita dalam penyelidikan yang lebih mendalam dan pemeriksaan secara menyeluruh terhadap tingkah laku seorang individu, (b) penelitian terhadap latar belakang dan kondisi dari individu, kelompok, atau komunitas tertentu dengan tujuan untuk memberikan gambaran yang lengkap mengenai subyek atau kejadian yang diteliti, dan (c) suatu penelitian yang dilakukan intensif, terinci dan mendalam 
terhadap organisme, lembaga atau gejala tertentu. Studi kasus ini digunakan karena subyek yang diteliti sempit dan terbatas.

Hasil penelitian menyebutkan bahwa mahasiswa Program Studi PGSD FKIP Universitas Muhammadiyah Palangkaraya tahun angkatan 2012 melaksanakan tugas individu dan tugas kelompok terlihat kemampuan mengajar mahasiswa terutama dalam hal percaya diri, berani tampil, suara keras dan jelas dan karakter/ciri khas belum sepenuhnya dimiliki sehingga tidak begitu dapat menguasai situasi dan kondisi kelas.

Kata Kunci: kompetensi mengajar, calon guru SD

\section{PENDAHULUAN}

Pembelajaran adalah kegiatan yang mengaktifkan seseorang untuk melaksanakan rencana yang dibuat terlebih dahulu berdasarkan pedoman yang telah ada. Seseorang tidak akan mempunyai kegiatan apabila ia tidak mempunyai rencana pelaksanaan pembelajaran. Rencana akan berhasil apabila kegiatan yang dibuat dapat menjadikan seseorang memiliki kompetensi. Kompetensi berasal dari proses bukan instan. Kompetensi akan berhasil apabila proses dimulai dari kemampuan dasar suatu keilmuan yang dicita-citakan.

Kompetensi guru dimulai dari kemampuan dasar mengajar. Mengajar memerlukan, (1) percaya diri; (2) berani tampil; (3) suara jelas dan keras; (4) mempunyai karakter/ciri khas; dan (5) pengetahuan yang luas. Percaya diri harus dimiliki oleh seorang calon guru professional. Percaya diri tidak dapat muncul begitu saja dalam kemampuan seseorang. Percaya diri tumbuh apabila seseorang melaksanakan perkuliahan melakukan berbagai tugas baik individu dan kelompok dari dosen. Tugas dilaksanakan maka akan menghasilkan aktivitas seseorang melakukan kompetensi. Berani Tampil merupakan hasil dari melatih
Guru berceramah menjelaskan materi menggunakan suara. Suara yang dikeluarkan harus jelas pengucapan huruf/angka nya sehingga orang lain tidak salah memahami dan keras yaitu suara dapat didengar dengan baik sehingga materi yang disampaikan dapat dipahami oleh orang lain. Karakter/ciri khas seseorang merupakan identitas yang menandakan bahwa itulah dirinya. Apabila karakter/ciri khas itu muncul dihadapan orang banyak orang sudah mengetahui bahwa itu si A. Pengetahuan yang Luas, Calon guru SD harus mempunyai pengalaman hidup yang luas mulai dari suka berorganisasi, mencari informasi dari internet, berprestasi, sering mengikuti pelatihan, sering membaca buku, dan berdiskusi dengan teman sejawat. Mengajar adalah menyampaikan pengetahuan pada anak didik dengan suatu harapan terjadi proses pemahaman.

Sardiman A.M. (2007) mengemukakan mengajar diartikan sebagai aktivitas mengorganisasi atau mengatur lingkungan sebaik-baiknya dan menghubungkan dengan anak, sehingga terjadi proses belajar. Beberapa komponen keterampilan mengajar dibagi menjadi tiga klasifikasi, yakni yang berkaitan dengan aspek materi, modal kesiapan dan keterampilan operasional (Sardiman A.M., 2007). Selain itu 
Seorang guru sekolah dasar harus memiliki kompetensi pedagogik, profesional, sosial dan kepribadian yang unggul.

Dengan adanya ruang lingkup kompetensi dasar mata pelajaran yang telah dipersempit ke taksonomi tujuan pendidikan menurut logika akan mudah seorang guru untuk mencapai target pengajaran materi sesuai dengan Rencana Pelaksanaan Pembelajaran (RPP). Berdasarkan latar belakang maka rumusan masalahnya adalah "bagaimanakah kompetensi mengajar mahasiswa Program Studi PGSD FKIP Universitas Muhammadiyah Palangkaraya"?

\section{TINJAUAN PUSTAKA}

Kartadinata, S dan Permana, J., 1997; Raka joni, 1983; Hasibuan dan Mudjiono, 1995, menyatakan pembelajaran dapat diartikan dari beberapa sudut pandang. Pertama, pembelajaran diartikan sebagai kegiatan menyampaikan pesan berupa pengetahuan, keterampilan, dan sikap dari guru kepada peserta didik. Kedua, pembelajaran dipandang sebagai suatu proses penggunaan seperangkat ketrampilan (teaching as a skill) secara terpadu. Ketiga, pembelajaran dipandang suatu seni, yang mengutamakan penampilan (kinerja) guru secara unik yang berasal-dari sifatsifat khas, dan perasaan serta naluri guru. Keempat, pembelajaran dipandang sebagai penciptaan suatu sistem lingkungan yang memungkinkan terjadinya proses belajar.

Joyce dan Weil, 1980 (dalam Usman, 2006) mengemukakan 22 model mengajar yang dikelompokkan ke dalam 4 hal, yaitu (1) proses informasi, (2) perkembangan pribadi, (3) interaksi sosial, (4) modifikasi tingkah laku.
Mursell dan Nasution (2002) berpandangan bahwa mengajar sebagai menyusun sejumlah kegiatan-kegiatan dalam hidup sekelompok manusia yang belajar. Kegiatan-kegiatan itu beraneka ragam ada di dalam ada di luar kelas, ada individual, ada pula dalam kelompok.

Sekolah dasar merupakan satuan pendidikan yang menyelenggarakan pendidikan enam tahun. Sekolah dasar merupakan bagian dari pendidikan dasar. $\mathrm{Di}$ dalam Peraturan Pemerintah Repbublik Indonesia Nomor 28 Tahun 1990 tentang Pendidikan Dasar disebutkan bahwa pendidikan dasar merupakan pendidikan sembilan tahun, terdiri atas program pendidikan enam tahun di sekolah dasar dan program pendidikan tiga tahun di sekolah lanjutan tingkat pertama (SLTP).

Ada tujuh jenis sekolah dasar (SD) di Indonesia, yaitu SD konvensional, SD percobaan, SD inti, SD kecil, SD satu guru, SD pamong, dan SD terpadu. Landasan yuridis sekolah dasar yaitu Undang-Undang Dasar (UUD) 1945, UndangUndang Republik Indonesia Nomor 2 Tahun 1989 tentang Sistem Pendidikan Nasional (UUSPN), dan Peraturan Pemerintah Republik Indonesia Nomor 28 Tahun 1990 tentang Pendidikan Dasar (PP Nomor 28 Tahun 1990).

Tujuan Institusional sekolah dasar, di dalam Buku I Kurikulum Pendidikan Dasar tahun 1994 dijelaskan bahwa pendidikan dasar bertujuan memberikan bekal kemampuan dasar kepada siswa untuk mengembangkan kehidupannya sebagai pribadi, anggota masyarakat, warga negara, dan anggota umat manusia serta mempersiapkan siswa untuk mengikuti pendidikan menengah (Bafadal, 2003). 
Dirjen Dikdasmen (1981) dalam Suharjo (2006) tugas guru di sekolah dasar mencakup tiga hal. Tugas guru yang pertama adalah tugas profesional yaitu mendidik (dalam rangka mengembangkan kepribadian), mengajar (dalam rangka mengembangkan kemampuan berfikir/kecerdasan) dan melatih (dalam rangka penerapan teknologi dan ketrampilan).

\section{METODE PENELITIAN}

Penelitian "Kompetensi Mengajar Calon Guru SD (Studi Kasus Mahasiswa Program Studi PGSD FKIP Universitas Muhammadiyah Palangkaraya)" dilaksanakan pada Program Studi PGSD FKIP Universitas Muhammadiyah Palangkaraya. Waktu penelitian dimulai dari bulan Maret sampai tanggal September 2014. Subjek penelitian adalah mahasiswa Program Studi PGSD FKIP Universitas Muhammadiyah Palangkaraya.

Penelitian ini merupakan penelitian pendekatan kualitatif, Riduwan (2005) mengemukakan Metode Kualitatif adalah metode penelitian yang digunakan meneliti pada kondisi objek ilmiah, dimana peneliti adalah sebagai instrument kunci. Penelitian kualitatif menggunakan lingkungan alamiah sebagai sumber data langsung. Situasi pendidikan baik dalam lingkungan keluarga, sekolah dan masyarakat, sebagaimana adanya (alami) tanpa dilakukan perubahan dan intervensi oleh peneliti, merupakan objek bagi penelitian kualitatif.

Penelitian kualitatif, sifatnya eksploratif (Silalahi, 2003:55; Sudjana dan Ibrahim, 2001:18) - Data yang diperoleh dari penelitian kualitatif seperti hasil pengamatan, hasil wawancara, hasil pemotretan, cuplikan tertulis dari dokumen, catatan lapangan, disusun peneliti dilokasi penelitian, tidak dituangkan dalam bentuk dan bilangan statistik.

Penelitian kualitatif ini menggunakan jenis strategi penelitian kasus. Silalahi (2003:62) dan Sudjana dan Ibrahim (2001:69-71) mengemukakan penelitian kasus adalah (a) studi yang akan melibatkan kita dalam penyelidikan yang lebih mendalam dan pemeriksaan secara menyeluruh terhadap tingkah laku seorang individu, (b) penelitian terhadap latar belakang dan kondisi dari individu, kelompok, atau komunitas tertentu dengan tujuan untuk memberikan gambaran yang lengkap mengenai subyek atau kejadian yang diteliti, dan (c) suatu penelitian yang dilakukan intensif, terinci dan mendalam terhadap organisme, lembaga atau gejala tertentu. Studi kasus ini digunakan karena subyek yang diteliti sempit dan terbatas.

\section{PEMBAHASAN}

\section{Penelitian Kompetensi Mengajar Dengan Tugas Individu}

Identifikasi kompetensi mengajar mahasiswa semester IV TA. 2013/2014 Program Studi PGSD FKIP Universitas Muhammadiyah Palangkaraya dengan menerapkan metode penelitian kualitatif dengan jenis strategi penelitian kasus. Identifikasi sementara ini berdasarkan dari tugas individu dan tugas kelompok, dari data hasil rekaman video dan observasi langsung maka dihasilkan beberapa hasil penelitian, yaitu:

1. Percaya Diri

Mahasiswa PGSD semester IV TA. 2013/2014 kurang percaya diri disaat menampilkan tugas individu, ini terlihat bahwa mereka masih gugup, selalu menunduk, grogi, 
kaku (hanya berdiri tanpa melakukan gerakan badan/bahasa tubuh) dan monoton menggunakan teks. Kurang percaya diri ini timbul karena mereka belum mempunyai pengetahuan yang luas tentang apa yang akan mereka presentasikan dan mereka kurang terbiasa untuk melakukan tugas individu yang sesuai dengan posisi mereka sebagai calon guru sekolah dasar.

2. Berani Tampil

Mahasiswa PGSD semester IV TA. 2013/2014 kurang berani tampil disaat menampilkan tugas individu, ini terlihat bahwa mereka masih menundukkan wajah (tidak berani melihat audiens atau kadang-kadang melihat), kurang berani menjelaskan sesuai kemampuan, masih membaca teks secara keseluruhan, menjelaskan dengan terputus-putus (atau masing sering menggunakan kata "eeeeeeeee") dan mereka hanya sekedar menyelesaikan tugas. Kurang berani tampil ini timbul karena mereka belum belajar secara maksimal dan selalu mengamalkan SKS (sistem Kebut Semalam) tentang apa yang akan mereka presentasikan dan mereka kurang terbiasa untuk melakukan tugas individu yang sesuai dengan posisi mereka sebagai calon guru sekolah dasar.

3. Suara Jelas dan Keras

Mahasiswa PGSD semester IV TA. 2013/2014 kurang jelas dan keras disaat menampilkan tugas individu, ini terlihat bahwa mereka masih kurang berani mengeluarkan suaranya, menjelaskan terus menerus tanpa memperhatikan tanda baca (membaca terus menerus), dan kurang mengerti pengaturan intonasi dan kecepatan. Kurang dapat mengeluarkan suara keras dan jelas karena mereka belum melakukan latihan sebelum tampil presentasi dan mereka kurang terbiasa untuk melakukan tugas individu yang sesuai dengan indikator penilaian dan posisi mereka sebagai calon guru sekolah dasar.

4. Mempunyai Karakter/Ciri Khas

Mahasiswa PGSD semester IV TA. 2013/2014 kurang menampilkan karakter/ciri khas disaat melaksanakan tugas individu, terlihat bahwa mereka kurang mengerti tentang kelebihan dan kekurangan diri sendiri, kurang memperhatikan sikap dan tingkah laku, dan kurang mengerti makna tugas individu. Kurang tampilnya karakter/ciri khas karena mereka kurangnya rasa tanggungjawab dalam melaksanakan tugas dan kurang terbiasa untuk melakukan tugas individu yang sesuai dengan posisi mereka sebagai calon guru sekolah dasar.

5. Pengetahuan yang Luas

Mahasiswa PGSD semester IV TA. 2013/2014 kurang memiliki pengetahuan yang luas karena mereka kurang belajar dan mencari informasi disaat menampilkan tugas individu, terlihat bahwa teks hasil tugas individu mereka kebanyakkan hanya copy paste dan kurang menampilkan hasil pemikiran mereka. Kurang pengetahuan yang luas karena mereka kurang mempunyai pengalaman, kehadiran mereka ke perpustakaan, dan masih banyak yang kurang menguasai teknologi, informasi, dan komputer dan mereka kurang terbiasa untuk melakukan tugas individu yang sesuai dengan posisi mereka sebagai calon guru sekolah dasar akhirnya penguasaan situasi dan kondisi kurang maksimal malah cenderung kurang memperhatikan. 


\section{Penelitian Kompetensi Mengajar Dengan Tugas Kelompok}

Identifikasi kompetensi mengajar mahasiswa semester IV TA. 2013/2014 Program Studi PGSD FKIP Universitas Muhammadiyah Palangkaraya dengan menerapkan metode penelitian kualitatif dengan jenis strategi penelitian kasus. Identifikasi ini berdasarkan dari tugas kelompok, dari data hasil rekaman video dan observasi langsung maka dihasilkan beberapa hasil penelitian, yaitu:

1. Percaya Diri

Mahasiswa PGSD semester IV TA. 2013/2014 kurang percaya diri disaat menampilkan tugas kelompok, ini terlihat bahwa mereka masih gugup, grogi, kaku dan monoton membaca teks. Kurang percaya diri ini timbul karena mereka belum mempunyai pengetahuan yang luas tentang apa yang akan mereka presentasikan dan mereka kurang terbiasa untuk melakukan tugas individu yang sesuai dengan posisi mereka sebagai calon guru sekolah dasar.

\section{Berani Tampil}

Mahasiswa PGSD semester IV TA. 2013/2014 kurang berani tampil disaat menampilkan tugas kelompok terlihat bahwa mereka masih mengadalkan teman yang pintar, kurang paham terhadap pertanyaan sehingga menjawab seadanya saja, dan tidak ada persiapan yang baik. Kurang berani ini karena mereka belum mempunyai kemampuan yang maksimal tentang apa yang akan mereka presentasikan dan mereka kurang ditekankan pada saat melaksanakan tugas kelompok bahwa semua anggota harus bisa menjawab pertanyaan dan membantu menjawab pertanyaan anggota yang lain dengan posisi mereka sebagai calon guru sekolah dasar.

3. Suara Jelas dan Keras

Mahasiswa PGSD semester IV TA. 2013/2014 kurang bersuara keras dan jelas disaat menampilkan tugas kelompok, terlihat bahwa mereka kurang mampu menelaah pertanyaan yang diberikan, belum terbiasa mengonsep suatu jawaban secara sistematis, dan kurang mempersiapkan mental. Kurang bersuara jelas dan keras karena mereka kurang mampu berpikir secara sistematis dalam menjawab pertanyaan sehingga terlihat ragu-ragu dalam menjawab tentang apa yang akan mereka presentasikan dan mereka kurang terbiasa untuk melakukan tugas kelompok secara benar yang sesuai indikator dan posisi mereka sebagai calon guru sekolah dasar.

4. Mempunyai Karakter/Ciri Khas

Mahasiswa PGSD semester IV TA. 2013/2014 kurang menampilkan karakter/ciri khas disaat menampilkan tugas kelompok, terlihat bahwa mereka hanya melaksanakan tugas diskusi (ada pertanyaan dan jawaban), kurang menguasai teknologi. Kurang menampilkan karakter/ciri khas karena mereka kurang dibimbing secara maksimal sewaktu mereka presentasi dan mereka kurang terbiasa untuk melakukan tugas kelompok dengan karakter/ciri khas yang sesuai dengan posisi mereka sebagai calon guru sekolah dasar.

5. Pengetahuan yang Luas

Mahasiswa PGSD semester IV TA. 2013/2014 kurang pengetahuan yang luas disaat menampilkan tugas kelompok, terlihat bahwa mereka kurang mampu menjawab pertanyaan secara benar, kurang logis, dan kurang mempunyai literatur. Kurang pengetahuan yang 
luas karena mereka kurang memaksimalkan waktu dalam mengerjakan tugas yang akan mereka presentasikan dan mereka kurang terbiasa untuk melakukan tugas kelompok dengan tanggungjawab dan sesuai dengan posisi mereka sebagai calon guru sekolah dasar.

Hasil penelitian tersebut didukung hasil wawancara dari beberapa mahasiswa.

\section{Percaya Diri}

Hasil wawancara dengan beberapa mahasiswa disimpulkan bahwa percaya diri selalu ada dalam diri mereka tetapi karena tugas-tugas yang kurang mengarah pada kemampuan untuk memperkuat percaya diri kurang dan kurang diarahkan maka mahasiswa tidak dapat melatih diri mereka sebagaimana kepribadian seorang guru semaksimal mungkin (doc.ady/wawancara/2014) jadi tugas banyak mengarah pada teroitis tidak praktis.

\section{Berani Tampil}

Hasil wawancara dengan beberapa mahasiswa disimpulkan bahwa berani tampil tergantung pada kepercayaan diri mereka sewaktu perkuliahanperkuliahan sebelumnya yaitu semakin sering tugas yang mengharuskan mereka tampil ke depan maka terbentuk dengan sendirinya berani tampil di depan teman-teman mereka sendiri (doc.ady/wawancara/2014).

\section{Suara Jelas dan Keras}

Hasil wawancara dengan beberapa mahasiswa disimpulkan bahwa suara jelas dan keras mereka belum maksimal dikeluarkan karena mereka mencontoh guru-guru sebelumnya yang ada di sekolah dasar berdasarkan hasil dari sekolah mereka sendiri guru tidak perlu mempunyai suara jelas dan keras karena kebanyakkan pembelajaran di sekolah dasar masih mencatat di papan tulis dan mendiktekan materi jadi mereka kurang sadar dengan hal ini (doc.ady/wawancara/2014).

\section{Karakter/Ciri Khas}

Hasil wawancara dengan beberapa mahasiswa disimpulkan bahwa kemampuan untuk menampilkan karakter/ciri khas belum mereka pahami sepenuhnya karena mereka masih kurang mengerti akan keperibadian mereka sendiri, apa kekurangan dan kelebihan mereka untuk dapat dijadikan karakter/ciri khas seorang guru yang baik dan sesuai dengan teori serta pedoman (doc.ady/wawancara/2014).

\section{Pengetahuan/wawasan yang luas}

Hasil wawancara dengan beberapa mahasiswa disimpulkan bahwa pengetahuan/wawasan yang mereka belum begitu meluas karena masalah klasik di setiap perguruan tinggi dan daerah yaitu kuantitas dan kualitas buku di perpustakaan baik diperguruan tinggi dan daerah belum memiliki rasio kecukupan yang memadai sehingga mereka dalam mengerjakan tugas hanya mengandalkan internet sebagai aspirasi dan rujukan. Itupun rujukan dari sumber yang sebenarnya belum tentu dapat dipercaya sehingga mereka kurang mampu menjelaskan tugas dan menjawab pertanyaan kurang begitu baik dan masih membaca teks (doc.ady/wawancara/2014).

Hasil penelitian tersebut didukung simpulan hasil wawancara dari beberapa dosen.

Percaya Diri

Hasil wawancara dengan beberapa dosen disimpulkan bahwa mahasiswa kurang percaya diri yaitu dapat dilihat dari penampilan presentasi tugas kurang begitu yakin kepada dirinya sendiri dan dalam menjawab pertanyaan kurang berani (doc.ady/wawancara/2014). 
Berani Tampil

Hasil wawancara dengan beberapa dosen disimpulkan bahwa mereka masih kurang berani tampil yaitu tugas tetap diharuskan tetapi mereka tampil ke depan masih gugup dan canggung sendiri padahal tampil di depan teman-teman mereka sendiri (doc.ady/wawancara/2014).

Suara Jelas dan Keras

Hasil wawancara dengan beberapa dosen disimpulkan bahwa mahasiswa kurang memiliki suara jelas dan keras mereka yaitu belum maksimal dikeluarkan karena mereka mencontoh guru-guru sebelumnya yang ada kebanyakkan melaksanakan proses pembelajaran di sekolah dasar masih mencatat di papan tulis dan mendiktekan materi jadi mereka kurang sadar dengan hal ini (doc.ady/wawancara/2014).

Mempunyai Karakter/Ciri Khas

Hasil wawancara dengan beberapa dosen disimpulkan bahwa kemampuan untuk menampilkan karakter/ciri khas belum mereka pahami sepenuhnya karena mereka masih kurang mengerti akan keperibadian mereka sendiri, apa kekurangan dan kelebihan mereka untuk dapat dijadikan karakter/ciri khas seorang guru yang baik dan sesuai dengan teori serta pedoman (doc.ady/wawancara/2014).

Pengetahuan/wawasan yang luas

Hasil wawancara dengan beberapa dosen disimpulkan bahwa pengetahuan/wawasan yang mereka belum begitu meluas karena mereka dalam mengerjakan tugas hanya mengandalkan internet sebagai aspirasi dan rujukan. Itupun rujukan dari sumber yang sebenarnya belum tentu dapat dipercaya sehingga mereka kurang mampu menjelaskan tugas dan menjawab pertanyaan kurang begitu baik dan masih membaca teks.

\section{KESIMPULAN dan SARAN}

\section{KESIMPULAN}

Kesimpulan yang dapat diambil berdasarkan penelitian yang telah dilakukan:

1. Kompetensi mengajar calon guru sekolah dasar Mahasiswa Program Studi PGSD FKIP Universitas Muhammadiyah Palangkaraya hanya sebatas gugur kewajiban melaksanakan tugas individu dan tugas kelompok dan kurang bertanggungjawab terhadap tugas individu dan kelompok karena belum maksimalnya mereka untuk memiliki indikator komptensi mengajar.

2. Mahasiswa belum dapat sepenuhnya menguasai situasi dan kondisi kelas karena mereka kurang memiliki pengetahuan/wawasan yang cukup baik untuk menampilkan karakter diri/ciri khas kepribadian mereka masing-masing.

\section{SARAN}

1. Pengembangan, variasi dan penguatan tugas individu dan tugas kelompok oleh setiap dosen.

2. Mahasiswa perlu sering dan terus menerus tiap semester melaksanakan tugas tampil di depan teman-teman mereka dengan kondisi yang nyata sama seperti di sekolah dasar baik dibiasakan pada situasi dan kondisi kelas rendah $(1,2,3)$ dan kelas tinggi $(4,5,6)$.

\section{DAFTAR PUSTAKA}

Bafadal, Ibrahim. 2003. Peningkatan Profesionalisme Guru Sekolah Dasar dalam Rangka Manajemen Peningkatan Mutu Berbasis Sekolah. Jakarta : Bumi Aksara 
Borich, G. D. 1994. Obervation Skills for Effective Teaching. New York : Macmillan Publishing Company

Bogdan, Robert C. dan Biklen, Sari Knopp. Qualitative Research for Education: An Introduction to Theory and Methods. Boston London Sydney Toronto: Allyn and Bacon, Inc.

BSNP. 2006. Panduan Penyusunan Kurikulum Tingkat Satuan Pendidikan (KTSP) Jenjang Pendidikan Dasar dan Menengah. Jakarta : Badan Standar Nasional Pendidikan (BSNP)

Iskandar. 2008. Metodologi Penelitian Pendidikan dan Sosial (Kuantitatif dan Kualitatif). Jakarta: Gaung Persada Press

Mursell dan Nasution. 2002. Mengajar Dengan Sukses (Successful Teaching). Jakarta : Bumi Aksara

Riduwan. 2005. Metode \& Teknik Menyusun Tesis. Bandung : Alfabeta

Silalahi, Gabriel Amin. 2003. Metodologi Penelitian dan Studi Kasus. Sidoarjo: Citramedia

Sudjana dan Ibrahim, 2001, Penelitian dan Penilaian Pendidikan, Sinar Baru Algensindo, Bandung

Sugiyono. 2007. Metode Penelitian Pendidikan (Pendekatan Kuantitatif, Kualitatif, dan $R \& D)$. Bandung: Alfabeta

Suharjo. 2006. Mengenal Pendidikan Sekolah Dasar Teori dan Praktek, Depdiknas, Dirjen Pendidikan Tinggi, Direktorat Ketenagaan, Jakarta

Suryosubroto, B. 1997. Proses Belajar Mengajar Di Sekolah. Jakarta : PT. Rineka Cipta

Usman, Moh. User. 2006. Menjadi Guru Profesional. Bandung : PT. Remaja Rosdakarya 